\title{
Polymorphisms in mitochondrial DNA of European and Africanized honeybees (Apis mellifera)
}

\author{
D. R. Smith and W. M. Brown
}

\author{
Laboratory for Molecular Systematics, Museum of Zoology, and Department of Biology, University of Michigan, Ann Arbor \\ (Michigan 48109, USA) \\ Received 15 June 1987; accepted 19 October 1987
}

Summary. This study demonstrates polymorphisms in both the length and in the restriction enzyme cleavage sites of honeybee mitochondrial DNA (mtDNA). The levels of variation are typical of those found in other metazoan species. These polymorphisms are potentially useful for the identification of Africanized bees in the western hemisphere and for study of honeybee phylogenetics.

Key words. Mitochondrial DNA; restriction site polymorphisms; Apis mellifera; Africanized honey bees.

The honeybee, Apis mellifera, is native to Eurasia and Africa and has been transported by humans over most of the world. It is divided into approximately 30 geographic subspecies which differ in behavior and morphology ${ }^{1-5}$. New World honeybees are hybrids of several subspecies, primarily European A.m.ligustica, mellifera, and carnica ${ }^{6-9}$. A.m. scutellata (formerly adansonii ${ }^{10}, 11$ ) from southern Africa was introduced into Brazil in 1956. An accident permitted escape of 26 swarms; their descendants established feral populations and hybridized with managed European bees, giving rise to the population known as Africanized bees ${ }^{12-14}$. This population, which has gained notoriety because of its aggressive nest defense ${ }^{13-15}$, has spread over most of South and Central America and is expected to establish feral populations in the United States within five years ${ }^{16-18}$ with undesirable consequences for public health, bee-keeping and agriculture ${ }^{17,19}$.

Effective methods are needed to monitor the spread of Africanized bees and to enable commercial bee breeders to certify non-Africanized stock. Variation in allozymes, nuclear DNA, morphology and cuticular hydrocarbons have been investigated as potential identification tools. Few polymorphic enzyme loci have been detected in honeybees ${ }^{20,29}$ and none of the allozymes in polymorphic systems are unique to the African subspecies $21,24,26,30,31$. The use of cuticular hydrocarbons is promising ${ }^{32-34}$, but their heritability has not been demonstrated. Recently Hall ${ }^{35}$ compared three American hives and one Africanized hive by probing fragments of nuclear DNA generated by restriction endonucleases with cloned fragments of low copy-number honeybee nuclear DNA sequences and found differences between the American hives and the Africanized hive; larger samples will be needed to evaluate this technique. Morphometric measurement is the most reliable identification tool currently available ${ }^{36-38}$ but it also has shortcomings. For example, some important characters, particularly size, are environmentally influenced; and the technique may be of little use in detecting Africanized bees which have back-crossed for several generations to European bees. All of these methods involve traits that are presumably biparentally inherited and subject to recombination, making interpretation of data difficult in populations containing hybrids and hybrid backcrosses.

Variation in mtDNA is potentially useful both for identification and for phylogenetic analysis of honeybee subspecies. Animal mtDNA is maternally inherited ${ }^{39-45}$ and does not appear to undergo recombination ${ }^{46,47}$. Thus the entire mitochondrial genome is inherited as a unit and hybrid populations retain the mtDNA characteristic of their maternal ancestors (except for new mutations). In the case of the Africanized bees, if $A . m$. scutellata possesses mtDNA which differs from that of European subspecies, the original 26 $A . m$. scutellata queens will have passed that genome intact to their progeny. Moritz et al. ${ }^{48}$ investigated mtDNA restriction fragment polymorphisms in nine honeybee hives representing three European subspecies, A.m.carnica,
A.m. ligustica and A.m. caucasica. They observed little variation among the three subspecies; using 7 restriction enzymes they found no differences between $A$. m. ligustica and $A$. m. carnica, and estimated $0.76 \%$ sequence divergence between these two subspecies and A.m.caucasica (two restriction sites present in caucasica which were absent in carnica and ligustica).

The study presented here investigates mtDNA from samples of American honey bees of European descent and Africanized bees from Brazil. A restriction site map for honeybee mtDNA is presented, and restriction site and length polymorphisms in samples of European (American) and Africanized bees are noted.

Materials and methods. Samples of adult worker honeybees were collected from two domesticated (USA 1 and USA 3) hives and one feral (USA 2) hive from Washtenaw County, Michigan, USA, and from five Africanized hives (BRZ1, BRZ A, BRZ B, BRZ C, BRZ D) from the apiary of the University of São Paulo, Ribeirão Preto, S. P., Brazil. A mtDNA sample from each hive was prepared from pooled flight muscle tissue of 100 adult worker bees. MtDNA was prepared according to the method of Brown ${ }^{49}$ with the following modifications to the tissue homogenization procedure: Flight muscle (intact thoraces) was ground on ice in a glass mortar and pestle in a buffer consisting of $0.25 \mathrm{M}$ sucrose, $10 \mathrm{mM} \mathrm{NaCl}, 10 \mathrm{mM}$ Tris, $100 \mathrm{mM}$ EDTA, pH 7.5; the tissue was then reground with a hand-held ground-glass tissue homogenizer. The tissue/buffer mixture was centrifuged for $5 \mathrm{~min}$ at $1200 \times \mathrm{g}, 4^{\circ} \mathrm{C}$ to pellet large cellular debris. The pellet was resuspended in fresh buffer and ground for $30-60 \mathrm{~s}$ with a Tekmar Tissumizer at the highest speed. This was then centrifuged for an additional $5 \mathrm{~min}$ at $1200 \times \mathrm{g}$, $4^{\circ} \mathrm{C}$. The pellets were then discarded. If the flight muscle tissue is not vigorously ground, the mitochondria adhere to the large cellular debris and are lost.

Each of the eight mtDNA samples was digested with restriction enzymes cleaving 6-bp sites (AccI, AvaI, BclI, EcoRI, HincII, HindIII, NdeI, PstI, PvuII, and XbaI). The resulting fragments were endlabeled with ${ }^{32} \mathrm{P}$-nucleosides, separated on $1.2 \%$ agarose and $3.5 \%$ polyacrylamide gels 50,51 , and visualized by autoradiography. A map of 6 base cleavage sites was constructed by means of double digests. The sizes of the mtDNA molecules were estimated by summation of restriction fragment sizes. Pairwise sequence divergence estimates for different mitochondrial genomes ('restriction morphs') were calculated from map comparisons using the method of Nei and Tajima ${ }^{52}$.

Results. Polymorphisms were found in the number of restriction sites for BclI, EcoRI, NdeI, and XbaI (e.g., fig. 1, 2). Four different restriction patterns (restriction morphs) were found (fig. 4): USA 2 and USA 3 shared one pattern; BRZA, BRZB, BRZC, and BRZD shared a second pattern; and USA 1 and BRZ 1 each had a unique pattern. There is also evidence for variation in the size of honey bee mtDNA. The mtDNAs from the American samples were approximately $16450 \mathrm{bp}$; the mtDNAs from the Brazilian samples were 


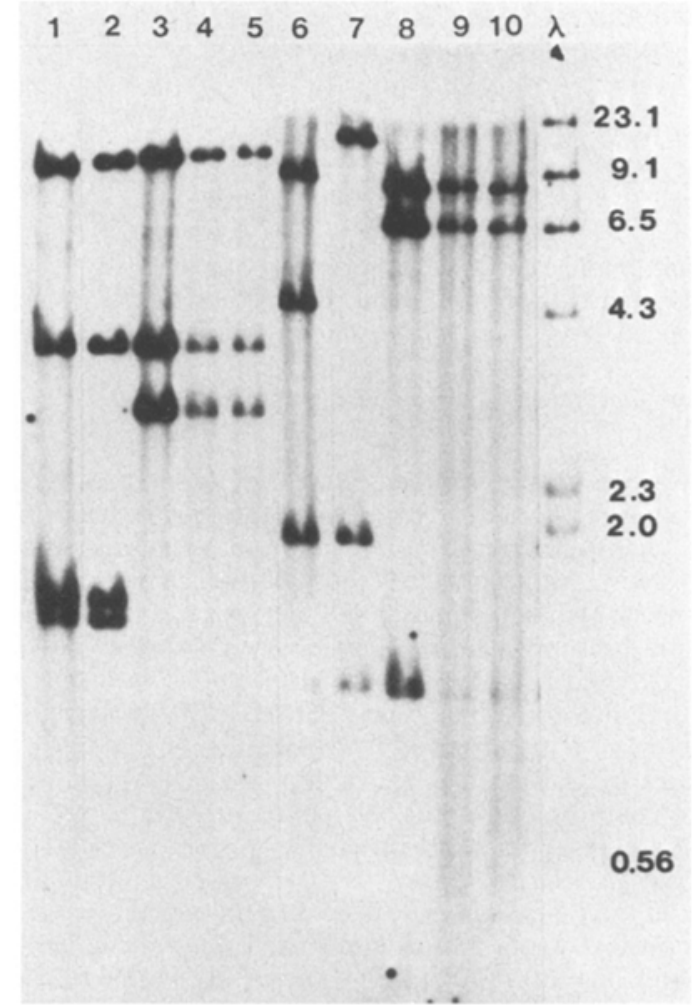

Figure 1. Autoradiograph of $1.2 \%$ agarose gel showing honeybee mtDNA digested with EcoRI (lanes 1-5) and XbaI (lanes 6-10). Lanes 1 and $6=\mathrm{USA} 1$; lanes 2 and $7=\mathrm{USA} 3$; lanes 3 and $8=\mathrm{BRZ} 1$; lanes 4 and $9=$ BRZ A; lanes 5 and $10=$ BRZ C. $\lambda=$ size, standard (HinD III digest of phage lambda replicative phase DNA); size of fragments in kilobase pairs $(\mathrm{kb})$.

$270 \mathrm{bp}$ larger, or $16720 \mathrm{bp}$. In addition the size of the two smallest BclI fragments differed between sample BRZ1 and the other Brazilian samples (figs 3,4). The map in figure 4 shows the location of the restriction sites generated by Aval, BclI, EcoRI, HincII, HindIII, NdeI, PstI, PvuII, and XbaI in each of the 4 restriction morphs; the location of the $270 \mathrm{bp}$ difference between the Brazilian and American samples; and the locations of size differences between BRZ1 and the other Brazilian samples. Slight variations in length were also observed among the three American hives, but these have not been mapped. Pairwise sequence divergence estimates for the 4 restriction morphs are presented in the table. Sequence divergence between the two restriction morphs found in the American samples is estimated to be $0.7 \% \pm 0.5$ and divergence between the two restriction morphs found in the Brazilian samples is $0.4 \% \pm 0.4$. Divergence between restriction morphs of American and Brazilian origin is estimated as $1.7 \% \pm 0.9$ to $2.6 \% \pm 1.1$. Because of the large stan-

Sequence devergence between mtDNA samples: The method of Nei and Tajima ${ }^{52}$ was used to estimate mean number of nucleotide substitutions per site and standard error of the mean (in parentheses) using cleavage site comparisons of the 9 enzymes mapped in figure 1; abbreviations as in figure 1.

\begin{tabular}{|c|c|c|c|c|}
\hline & USA 1 & USA 2,3 & BRZ 1 & $\mathrm{BRZ} A, \mathrm{~B}, \mathrm{C}, \mathrm{D}$ \\
\hline USA 1 & * & $0.007(0.005)$ & $0.017(0.009)$ & $0.012(0.007)$ \\
\hline USA 2,3 & & $*$ & $0.026(0.011)$ & $0.021(0.010)$ \\
\hline BRZ 1 & & & $*$ & $0.004(0.004)$ \\
\hline \multicolumn{3}{|c|}{$\mathrm{BRZ} A, \mathrm{~B}, \mathrm{C}, \mathrm{D}$} & & * \\
\hline
\end{tabular}

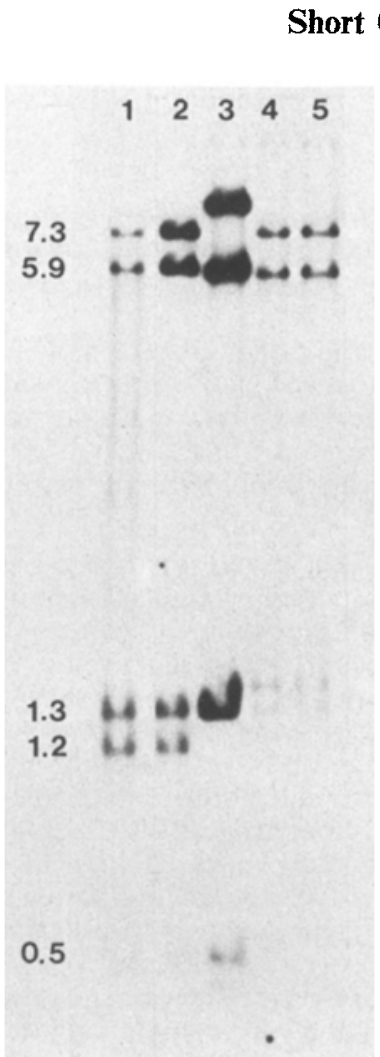

Figure 2. Autoradiograph of $1.2 \%$ agarose gel showing honeybee mtDNA digested with Bcll. Lane $1=$ USA 1 ; lane $2=$ USA 3 lane $3=\mathrm{BRZ}$ 1; lane $4=\mathrm{BRZ} A$; lane $5=\mathrm{BRZC}$. (The two smallest fragments in each lane are poorly resolved on agarose gels). Size of fragments in lane 1 given in $\mathrm{kb}$.

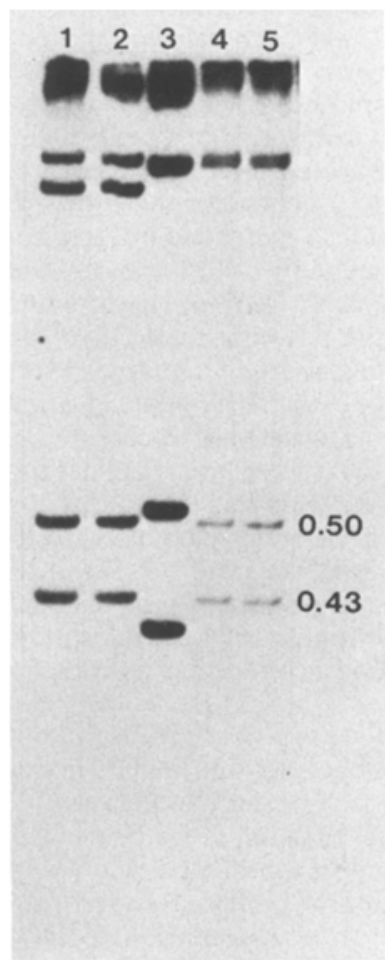

Figure 3. Autoradiograph of $3.5 \%$ polyacrylamide gel showing honey bee mtDNA digested with BclI. Lane $1=$ USA I; lane $2=$ USA 3; lane $3=$ BRZ 1 ; lane $4=$ BRZA; lane $5=$ BRZC. Size of fragments in lane 5 given in $\mathrm{kb}$. Note the variation in the size of the two smallest fragments in lane 3 compared to the other lanes. (Larger fragments are poorly resoived on polyacrylamide gels.) 


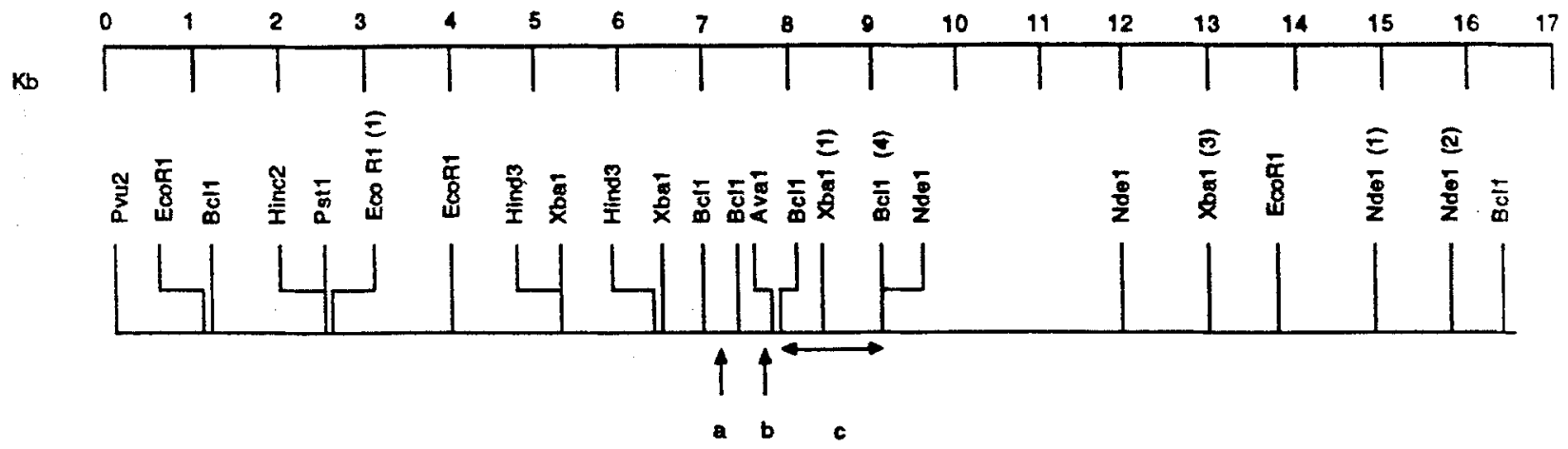

Figure 4. Cleavage map for mtDNAs from eight hives of Apis mellifera hybrids. The cleavage site for PvulI was arbitrarily chosen as the starting point for the map. Abbreviations: Kb: kilobase pairs; USA 1 and USA 3 : American bees of presumed European ancestry, domestic hives; USA 2: American bees of presumed European ancestry, feral hive: BRZ1, A, B, C, D: Africanized bees from Brazil.

Locations of restriction sites are accurate within $5 \%$. Restriction sites without an identifying number were common to all samples. Restriction sites followed by an identifying number (in parentheses) are only found in some samples: (1), present in American samples (USA 1, 2, and 3), absent in Brazilian samples (BRZ1, A, B, C, D); (2), present in USA 2 and USA 3; (3), present in USA 1 and all Brazilian samples; (4) present in all samples except BRZ1. The NdeI and BclI site at $9.0 \mathrm{~kb}$ were

dard errors these differences are not significant; that is, these data are not sufficient to show that significantly more base pair substitutions have accumulated between the 'American' and 'Brazilian' mitochondrial genomes than between the two 'American' genomes or between the two 'Brazilian' genomes. The large standard error in these estimates may be reduced in the future by mapping additional restriction sites.

Discussion. These results provide evidence for levels of variation in honeybee mtDNAs that are well within the range typically observed for metazoan species ${ }^{45}$. These results also show that there is more variation in honeybee mtDNA than the study of Moritz et al. ${ }^{48}$ initially indicated.

Two types of comparisons can be made using data from mtDNA restriction site maps: estimates of sequence divergence between mitochondrial genomes (above and in the table); and comparison of the mitochondrial genomes in different populations. To make comparisons among populations, for example comparisons among the honeybee subspecies or between European and African honeybee populations, it is necessary to determine the mtDNA restriction site patterns of a large number of individuals in each population and compare the frequencies of the restriction morphs in each population. These data are currently being collected for populations of A.m. mellifera, A.m. carnica, A.m. ligustica, A.m. scutellata, and A.m.capensis. This survey will determine if differences exist in the mitochondrial genomes of morphologically recognized subspecies, and provide data that can be used for an independent test of earlier hypotheses of honeybee phylogeny based on morphology and behavior $^{2,5,11}$.

If particular restriction morphs or particular mtDNA lengths prove to be characteristic of A.m.scutellata, these characters can also be used as genetic markers in the study of Africanized bees in the New World. Because animal mtDNA is maternally inherited and does not recombine, mtDNA markers could be used to identify matrilinial descendents of the originial introduced $A$.m. scutellata queens. MtDNA markers also make it possible to identify the maternal parent of hybrids so that it would be feasible to study the pattern of gene flow between the European and Africanized honeybee populations as the latter enter and occupy new habitats. For example it would be possible to determine if the spread of indistinguishable; however the BelI site was absent in BRZ1, while the NdeI site was present in all samples. The PstI and HincII sites at $2.4 \mathrm{~kb}$ are approximately $10 \mathrm{bp}$ apart, with Hincll at 2.44 and PstI at 2.45; this is inferred from PstI/EcoRI and HincII/EcoRI double digestions and comparison, on a $3.5 \%$ polyacrylamide gel, of the length of the fragments from the EcoRI site at $2.54 \mathrm{~kb}$ to the PstI and HinclI sites. The HindIII and $\mathrm{XbaI}$ sites at $5.2 \mathrm{~kb}$ are located at 5.18 and $5.23 \mathrm{~kb}$, respectively. The arrows below the map indicate the locations of size variation. Brazilian samples were 270 bp larger than American samples; the additional 270 base pairs occur in the region between the two BclI sites indicated by the horizontal arrow (c). The two BclI restriction fragments indicated by the vertical arrows ( $\mathrm{a}$ and $\mathrm{b}$ ) were $0.41 \mathrm{~kb}$ and $0.56 \mathrm{~kb}$ in length in sample BRZ 1, and $0.43 \mathrm{~kb}$ and $0.54 \mathrm{~kb}$ in length in all other samples.

Africanized bees is due primarily to gene flow from Africanized males (drones) mating with European queens (in which case bees with behavioral and morphological traits characteristic of Africanized bees would carry European mtDNA), or to the dispersal of Africanized queens in swarms (in which case most Africanized bees would carry A.m. scutellata $m t D N A)$, or if each occurs at a different stage in the expansion of the Africanized population.

Acknowledgments. We thank R. Morse, D. De Jong, C. Henderson and the Department of Genetics, University of São Paulo, Ribeirão Preto, S. P. Brasil for samples of Africanized bees, T. E. Dowling for computer programs, T. E. Dowling, R. Harrison, C. Moritz, and L. Vawter for technical advice, and R. Hagen, C. Moritz, L. Vawter and an anonymous reviewer for comments on the manuscript. Support for DRS was provided by the Michigan Society of Fellows, and research support, in part, by grants from NIH (GM 30144 and RR 07050) and NSF (BSR 8516645) to WMB. This is dedicated to the memory of the late Mr Norton Williams, who introduced DRS to the study of honeybees.

1 Dietz, A., in: Social Insects, vol. 3, p. 323. Ed. H. H. Herman. Academic Press, New York 1982.

2 Ruttner, F., in: Traité de Biologie de l'Abeille, tome I. Biologie et Physiologie générales, p. 27. Ed. R. Chauvin, Masson et Cie., Paris 1968.

3 Ruttner, F., Proc. 25th Int. Apic. Congr., Grenoble, France, p. 347. Apimondia Publishing House, Bucharest 1975.

4 Ruttner, F., in: The Hive and the Honeybee, p. 19. Eds Dadant and Sons. Hamilton, Illinois 1975.

5 Ruttner, F., Tassencourt, L., and Louveaux, J., Apidologie 9 (1978) 363.

6 Oertel, E., Am. Bee J. 116 (1976) 70, 114, 128, 156, 214, 260, 290.

7 Pellet, F. C., History of American Bee-Keeping. Collegiate Press, Inc., Ames, Iowa 1938.

8 Townsend, G. F., and Crane, E., in: History of Entomology, p. 387. Eds R. F. Smith, T. E. Mittler, and C. N. Smith. Annual Reviews, Inc., 1973.

9 Watkins, L. H., Am. Bee J. 108 (1968) 145, 190, 232, 362 (1968).

10 Fletcher, D. J. C., A. Rev. Ent. 23 (1978) 151.

11 Ruttner, F., Proc. 28th Int. Congr. Apiculture, Acapulco, Mexico, p. 278. Apimondia Publishing House, Bucharest, Romania 1981.

12 Kerr, W. E., S. Afr. Bee J. 39 (1967) 3.

13 Michener, C. D., BioScience 23 (1973) 523.

14 Michener, C. D., A. Rev. Ent. 20 (1975). 399

15 Collins, A. M., Rinderer, T. E., Harbo, J. R., and Bolten, A. B., Science 218 (1982) 72 . 
16 Taylor, O. R., Bee World 58 (1977) 19.

17 Taylor, O. R., Bull. ent. Soc. Am. 31 (1985) 15.

18 Taylor, O. R, and Spivak, M., Bee World 65 (1984) 38.

19 Rinderer, T. E., Am. Bee, J. 126 (1986) 98, 128

20 Brueckner, D., Experientia 30 (1974) 618.

21 Contel, E. P. B., Mestriner, M. A., and Martins, E., Biochem. Genet. 15 (1977) 859 .

22 Del Lama, M. A., Mestriner, M. A., and Paiva, J. C. A., Rev. Brasil. Genet. 8 (1985) 17.

23 Hung, A. C. F., and Vinson, S. B., Heredity 38 (1977) 409

24 Martins, E., Mestriner, M. A., and Contel, E. P. B., Biochem. Genet. 15 (1977) 357

25 Mestriner, M. A., Nature 223 (1969) 188

26 Mestriner, M. A., and Contel, E. P. B., Genetics 72 (1972) 733.

27 Sheppard, W. S., and Berlocher, S. H., J. Apic. Res. 23 (1984) 64

28 Sheppard, W. S., and Berlocher, S. H., J. Hered. 76 (1985) 45.

29 Sheppard, W. S., and McPheron, B. A., Apidologie 17 (1986) 21.

30 Nunamaker, R. A., and Wilson, W. T., J. Kansas ent. Soc. 54 (1981) 704.

31 Nunamaker, R. A., Wilson, W. T., and Haley, B. E., J. Kansas ent. Soc. 57 (1984) 622

32 Carlson, D. A., and Bolton, A. B., Bull. ent. Soc. Am. 30 (1984) 32

33 Francis, B. R., Blanton, W. E., and Nunamaker, R. A., J. apicult. Res. 24 (1985) 13

34 McDaniel, C. A., Howard, R. W., Bloomquist, C. J., and Collins, A. M., Sociobiology 8 (1983) 287.

35 Hall, H. G., Proc. natl Acad. Sci. USA 83 (1986) 4874.

36 Daly, H. V., Proc. 25th Int. Apic. Congr., Grenoble, France, p. 356. Apimondia Publishing House, Bucharest 1975.

37 Daly, H. V., and Balling, S. S., J. Kansas ent. Soc. 51 (1978) 857.
38 Daly, H. V., Hoelmer, K., Norman, P., and Allen, T., Ann. ent. Soc Am. 75 (1928) 591

39 Dawid, I. B., and Blackler, A. B., Devl Biol. 29 (1972) 152

40 Giles, R. E., Blanc, H., Cann, H. M., and Wallace, D. C., Proc. nat Acad. Sci. USA 77 (1980) 6715

41 Harrison, R. G., Rand, D. M., and Wheeler, W. C., Science 228 (1985) 1446.

42 Hutchinson, C. A. III, Newbold, J. E., Potter, S. S., and Edgell, M. H., Nature 251 (1974) 536.

43 Lansman, R. A., Avise, J. C., and Heuttel, M., Proc. natl Acad. Sci. USA 80 (1983) 1969.

44 Reilly, J. G., and Thomas, C. A. Jr, Plasmid 3 (1980) 109.

45 Avise, J. C., and Lansman, R. A., in: Evolution of Genes and Proteins, p. 147. Eds M. Nei and R. K. Koehn. Sinauer Assoc., Inc., Sunderland, Mass. 1983.

46 Brown, W. M., in: Evolution of Genes and Proteins, p. 62. Eds M. Nei and R. K. Kochn. Sinawer Assoc., Inc, Sunderland, Mass. 1983

47 Brown, W. M., in: Monographs in Evolutionary Biology - Molecular Evolutionary Genetics p. 95 Ed. R. J. MacIntyre. Plenum Press, New York 1985.

48 Moritz, R., Hawkins, C. F., Crozier, R. H., and Mackinley, A. G. Experientia 42 (1986) 322

49 Brown, W. M., Ann. N.Y. Acad. Sci. 361 (1981) 119

50 Brown, W. M., Proc. natl Acad. Sci. USA 77 (1980) 3605.

51 Ferris, S. D., Wilson, A. C., and Brown, W. M., Proc. natl Acad. Sci. USA 78 (1981) 2432.

52 Nei, M., and Tajima, F., Genetics 97 (1983) 145

$0014-4754 / 88 / 030257-04 \$ 1.50+0.20 / 0$

(C) Birkhäuser Verlag Basel, 1988

\title{
C-band differentiation between the chromosomes of two subspecies of the chironomid midge Chironomus thummi
}

\author{
K. Hägele and H. Speier \\ Institut für Genetik, Ruhr-Universität Bochum, P.O. Box 1021 48, D-4630 Bochum 1 (Federal Republic of Germany) \\ Received 13 July 1987; accepted 10 November 1987
}

Summary. The metaphase chromosomes of Chironomus th. thummi contain approximately $17 \%$ more pericentric C-band heterochromatin than the chromosomes of Chironomus th. piger with $11 \%$ heterochromatin. In $C h$. th. thummi, the proportion of heterochromatin appeared to be much larger in metaphase chromosomes than in polytene chromosomes. This discrepancy is interpreted as being due to the specific chromosome organization and not as the result of an underreplication of heterochromatin during polytenization.

Key words. Chironomus th. thummi; Ch. th. piger; metaphase chromosomes; heterochromatin.

The two subspecies of Chironomus thummi, Ch. th. thummi and $C h$. th. piger, are very closely related and morphologically nearly indistinguishable ${ }^{1}$. Only regional differences in the banding pattern of their polytene chromosomes allow a reliable taxonomic identification ${ }^{2}$. There is, however, no discrimination possible between the metaphase chromosome complements of the two subspecies. This hampers the cytological analysis of the chromosome segregation in the germ line of the hybrids and their progeny during the study of the phenomenon of non-reciprocal gonadal dysgenesis ${ }^{3,4}$. Here we describe differences between metaphase chromosomes of the $C h$. th. thummi and the $C h$. th. piger complement observed after a strong modification of the routine C-banding method.

Material and methods. Neural ganglia and testes of Chironomus thummi piger and Ch. thummi piger $\times C h$. thummi thummi hybrid larvae were treated in a $0.1 \%$ sodium citrate solution for $1 \mathrm{~min}$. For C-banding, the routine fixation procedures and treatment times were modified. The tissues were fixed in $50 \%$ acetic acid, squashed and postfixed in cold methanol : glacial acetic acid (3:1) for $24 \mathrm{~h}$. Air-dried slides were treated with $0.2 \mathrm{~N} \mathrm{HCl}$ for $1 \mathrm{~h}$, rinsed in distilled water and incubated in $5 \% \mathrm{Ba}(\mathrm{OH})$, for $7 \mathrm{~min}$. at $50^{\circ} \mathrm{C}$. After rinsing, the slides were incubated in $2 \times \mathrm{SSC}$ for $1 \mathrm{~h}$ at $60^{\circ} \mathrm{C}$, rinsed, air-dried and stained in a $10 \%$ Giemsa phosphate buffer solution ( $\mathrm{pH} \mathrm{6.8)} \mathrm{for} 15 \mathrm{~min}$, rinsed and air-dried. The banded chromosomes were photographed and enlarged with a projector. The banded and the total chromosome areas of the chromosomes were then measured using a Videoplan system analyzer.

Results and discussion. The karyotype of both chironomids consists of three pairs of long metacentric and one pair of short acrocentric chromosomes ${ }^{2}$. As shown in the figure (a), in the hybrids homologous thummi and piger metaphase chromosomes cannot be distinguished from one another after conventional orcein staining. After $\mathrm{C}$-banding, however, 4 out of the 8 chromosomes of the complement show large and darkly staining pericentric regions (fig., b). The other 4 chromosomes reveal only small dark spots at the centromeric position. From C-banding results of the pure piger metaphase plates (fig., c) it becomes obvious that in hybrids (fig., b) those chromosomes with the small dark regions (C- 